\title{
The Development of Student Religiosity in Schools in The Industrial Revolution Era 4.0
}

\author{
Ahmad Rifa'l, Dewi Fatmawati \\ Teacher of Islamic Religious Education in SMA Muhammadiyah 16 Jakarta 13460, Indonesia \\ Teacher of Islamic Religious Education in SMKN 1 Cilegon Banten, 42424 Indonesia \\ Email: azka2thn@gmail.com and dewifatma12@gmail.com
}

\section{ARTICLE INFO}

Date received : 28 June 2020

Revision date : 01 September 2020

Date received : 15 September 2020

Keywords:

Industrial Revolution

Educational Reformulation

School Religiosity

\begin{abstract}
The era of the industrial revolution 4.0 has brought about changes in social interaction. Initially, particular communication has changed to become universal. Therefore, education readiness is needed in Indonesia to welcome it, especially in matters of religiosity. The purpose of this study is to develop students' religious attitudes in schools in the face of the industrial revolution. The object of this study is the attitude of the religiosity of high school students in Jakarta. The scope of this research is the culture of the school, the character of students, and the religious practice of high school students in Jakarta. The method used in this study is a qualitative method with literature research and field visits to several schools in Jakarta. The finding of this study is the attitude of students' religiosity in the era of the industrial revolution 4.0 has shown an encouraging thing, it just needs to be developed following the rapid information technology. The use of digital technology needs to be improved but still in the guidance and supervision of teachers in schools.
\end{abstract}

\section{INTRODUCTION}

Industry 4.0 is the term used to begin the fourth era of the industrial revolution. In this world, the industrial revolution has happened four times. The first was in 1784 marked by the discovery of a steam engine by James What, which replaced the work of human labor in all fields of industry. Then continued in the 19th century, with the use of electricity in all industrial sectors. The third revolution occurred in 1970 with the use of computerization and manufacturing in the industrial field. And now the world is entering the fourth era of the industrial revolution, with the use of interconnection, data analysis, sensor technology integrated into one to develop the industrial world.

The term Industry 4.0 was originally born in Germany when the Hannover Fair was held in 2011
(Kagermann dkk, 2011). Germany has a big interest in this matter because Industry 4.0 is part of the policy plan development called the High-Tech Strategy 2020. The policy aims to maintain right Germany always is foremost in the manufacturing world (Henning, 2013). Some other countries also participated in realizing the concept of Industry 4.0 but use different terms like smart factories, industrial internet of things, smart industry, or advanced manufacturing. despite having the mention of different terms, everything has the same goal is to increase competitiveness in each country's industry is facing a very dynamic global market. The condition was caused by the rapid development of digital technology utilization in various fields.

The industrial revolution 4.0 will bring many changes. but will cause many kinds of impacts. The 
positive impact is that the industry will be more effective and efficient. But there will be negative impacts that arise, for example like the reduction of human labor because they will be replaced by robots and machines. The world is currently watching the effects of the industrial revolution 4.0. Various opportunities are there, but on the other hand, many challenges must be faced.

Based on some of these explanations it is appropriate with that delivered by Zhou et al. (2015), in a manner general there are five big challenges to be faced namely aspects of knowledge, technology, economics, social, and politics. To answer the challenge, planning and strategy are needed in terms of regulators, academics, and practitioners (Hoedi \& Wahyudi, 2018).

In the world of Islamic education, sensitivity to this revolution is still not felt. Low-quality resources are supported by the lack of creativity of educators in delivering Islamic education, so the strategic position of Islamic religious education as a control for technological advancement is lost. The strong flow of digital information instead often drags educators into the utterance of hate and the spread of false information.

Until now there has not been obtained comprehensive and significant research results on the learning outcomes of Islamic education in schools both public and private from various levels. Various studies relating to religious education in schools have been conducted by several groups, but they are still conceptual and partial. The Ministry of Religion Research and Development Agency and the Ministry of Religion has several times researched religious education in schools: research on the competence of Islamic Education teachers at several provinces, research on the readiness of the Islamic religious education teacher in implementing national standard school exams in high schools and research on the diversity of high school students have not thoroughly touched on religious learning students because this is what is urgent.

However, from the existing research, it can be expected that the learning outcomes of Islamic education in schools are very varied, ranging from poor quality to high-quality learning outcomes. The learning developed so far is always placing the teacher as the center of learning so that the target of learning is science as the teacher's giving to students (transfer of knowledge) in the form of mastery of the material and is always oriented to the values outlined in the form of numbers. Thus, the dominance of the teacher will destroy the creativity, independence, and originality of students. Also, the delivery of learning is a more normative text. Religiosity or religious education that should have been formed through religious education is neglected or failed to be realized.

Islamic religious education material presented in schools is still a lot of repetition with the previous level. Besides, Islamic religious education material is studied independently and does not depend on other fields of study, so that Islamic subjects are not accepted as a way of life and are responsive to students' needs and the challenges of change. Even the presence of Islamic religious education courses will certainly be boring and less challenging. The method of Islamic learning in schools is conveyed by some teachers by way of indoctrinating students and only focusing on the cognitive realm. Teachers are busy teaching religious knowledge and insights, but they are negligent to teach students how to be good human beings, to love, respect others, care for the environment, hate hypocrisy, lies, and so on. From the phrases described above, it can be understood that the implementation of Islamic education in schools is currently facing several pressing problems to be resolved. If not, it is feared that the main mission intended to be carried out by Islamic religious education will fail.

The study of Islamic religiosity in the era of the industrial revolution needs to be reformed or at least reformulated again. So that the mastery of technology is maximally achieved, but does not change the morality and Islamic values taught by Allah and His Messenger.

\section{LITERATURE REVIEW}

The definition of religiosity is a system of beliefs and complex attitudes and rituals that connect an individual with one being or with something divine. Religiosity is a comprehensive unitary element, which makes a person called a religious person, and does not merely claim to be a religious person. Religiosity includes religious knowledge, religious beliefs, religious ritual practices, religious experiences, religious behavior (morality), and social religious attitudes. In Islam, religiosity is largely reflected in the practice of faith, sharia, and morals, or other terms, it is called Faith, Islam, and Ihsan. If all elements have been owned by someone, then he is a truly religious person (Annisa F, 2016). In the book of religious psychology, Zakiah Daradjat put forward the terms religious awareness and religious experience. Religious awareness is the aspect of religion that is felt in the mind and can be tested through introspection, or can be said to be a mental aspect of religious activity (Zakiah Darajat, 1999). Religious experience is an element of feeling in religious awareness, that is, feelings that lead to beliefs generated by actions (Jalaluddin, 2008). Whatever the term used by experts to refer to the religious aspect in humans, points to the fact that religious activities are indeed inseparable from human life. In it, the

re are various things concerning moral or morals, as well as one's faith and devotion (Spinks, 1963).

The word "din" cannot be equated with the word religion or religion in terminology. Because the 
meaning of the din is the rule of God placed through the mouth of His Prophets (Al-Ghazi: 2000). From this religious term came the term religiosity. Although derived from the same word but in its use, the term religiosity has a different meaning from religion. The word religion refers to the formal aspects relating to rules and obligations; religiosity refers to aspects of religion that have been internalized by the individual in the heart. Religiosity is often defined by diversity. Religiosity is understood as the extent of knowledge, how sturdy beliefs are, how much the implementation of worship, and the rules and appreciation of the religion they profess. For a Muslim, religiosity can be known from the extent of knowledge, belief, implementation, and appreciation of the religion of islams.

Hawari in Adi \& Wahid (2020) mentions that religiosity is the appreciation of religion and the depth of belief expressed by performing daily worship, praying, and reading the Qur'an. According to Glock \& Stark, there are five dimensions which are the essence of religiosity. Religiosity according to them is how committed a person is on the five substances of religious teachings. These five substances by Glock \& Stark, called the ideological, the ritualistic, the experiential, the intellectual, and the consequential (Stark \& Glock 1965). Based on the description above, it can be concluded that religiosity is the depth of appreciation of one's religious sense and one's belief in the existence of God which is realized by obeying orders and avoiding the prohibition with full sincerity of heart and with all body and soul.

Religiosity or a person's religion is very much determined by many things, including the factors of education, family, experience, and exercises carried out in childhood. A teenager who during his childhood had religious experiences from his parents, social environment, and friends who obeyed religious orders and received religious education both at home and at school was very different from children who had never received religious education at his childhood, then when he grows up he will not feel how important religion is in his life. People who get intense religious education both at home and at school and in the community tend to live within religious rules, accustomed to practice worship, and fear to violate religious restrictions (Syahridlo in Adi \&Wahid 2020).

Technological progress is a must and is part of God's grace. Therefore, in responding to technological advances it must be based on a spirit of gratitude for God's gift so that technology will be appropriate. Religiosity in the era of the industrial revolution must grow and develop in line with the technology itself. Easy access to one's interactions with others throughout the world, across cultures and ideas, requires that one has a good understanding of religion and a strong sense of diversity. A Muslim must have personal piety and social piety, especially when he must interact with heterogeneous communities.

Today the very big challenge for this nation in facing industrial revolution 4.0 is the character of the people who are not ready to face differences of opinion. With the opening of insight and information universally, every person has the potential to access anything taboo to be discussed so that everything can be displayed vulgarly in their hands. Indonesian society today is still confined to the old mindset which requires that a person can only be in groups and be friends with people who are in the same ideas and their understanding. If this mindset is maintained then what happens is great friction in the community because the opening of the dimensions of space and time makes it impossible not to collide with differences.

Islam encourages people to be sensitive to change because that change is sunatullah. This change then becomes a challenge for the religion of Muslims in this modern era. In the secularist theses, modern humans put religion away from the public domain and put forward the rational aspect. This mindset is because religion is considered unable to walk with science and hinders the pace of modernity. Though such a thesis has a big mistake. Besides, because it has also been disputed by social theorists like Peter L. Berger. This mistake is also not by the Qur'anic verses which praise those who think. Allah SWT praised them in the Qur'an surah Ali Imran [3]: 190, Verily in the creation of the heavens, the earth, and the difference between day and night, there are signs (His power) for people to think.

Responding to the above verse, globalization encourages people, especially religious people, to be able to face the progress of the times. They must be able to seize the opportunity and face the challenges of the 21st century. This is because the problem of building civilization is not from religious teachings, but humans. And to prepare people to be dynamic along with the times, the right learning model is needed.

Seeing that, the Industrial Revolution 4.0 does not need to be considered a threat to religion, on the contrary religion is not a threat to the Industrial Revolution 4.0. In this case, it is important to emphasize the importance of aligning science and technology with religion. Science and technology must always be based on the moral values of religion so as not to damage human values. While religious teachings must be brought closer to the context of modernity so they can be compatible with all times and places.

To realize all this, religious education becomes very important, especially in the young generation of this nation. Studying proper and measured religiosity will create a generation of Muslims who 
are personable, polite, tolerant of differences, and responsive to the times.

\section{METODE}

The method used in this research is a qualitative descriptive method with literature research and field visits to several schools in Jakarta. In this study, researchers wanted to describe and explore data about the development of school religiosity learning in the era of the industrial revolution 4.0 then analyze it.

Data in this study were obtained from three sources:

\section{Al Qur'an and relevant Islamic books.}

\section{Books and journals.}

\section{Field observations of schools in Jakarta.}

In this study, researchers used source triangulation, namely by comparing data obtained from various sources to draw a valid conclusion (Ezmir, 2012)

\section{RESULTS AND DISCUSSION}

\section{RESULTS \\ The model of development of religiosity school in the era of the industrial revolution 4.0}

The development of religious understanding or religiosity in schools during the industrial revolution can be realized in various aspects of student life, not only in the implementation of worship but also when carrying out other activities that are driven by supernatural forces. Not only related to activities that can be seen with the eye, but also activities that are not seen and occur in the hearts of students.

In developing religiosity in students, of course, steps are needed to increase faith and godliness in God. The stages of increasing student religiosity require the involvement of families, schools, and communities. Maximum support from family and community environment in the application of religious values will determine the level of success of children's religiosity in daily life. This means that religiosity is not only left entirely to schools as formal educational institutions but also requires the support of family and the community environment.

Islamic Religious Education in schools aims to foster and enhance faith through the provision and fertilization of students' knowledge, appreciation, practice, and experience of Islam so that they become Muslims who develop in terms of faith, piety, nation, and state, and to be able to continue education at a higher level. The process of internalizing religious values will be realized if there is refraction carried out in schools by the school community. It is hoped that the habituation will shape the character of the students.

This school culture is the psychological experience of all students both social, emotional, and intellectual that is absorbed by them when they are in the school environment. Psychological responses of students to things that occur every day such as the way teachers and school staff behave, administrative services, implementation of school rules, conditions and school canteen services, room management, class cleanliness, and comfort of the school environment, all shape the school culture. All of this will seep into the hearts of the school community including students who in turn form patterns of values, attitudes, habits, and behavior.

There are several reasons for the need for Islamic Religious Education to be developed into school culture, namely :

1. Parents have the prerogative to choose schools for their children. Quality schools are increasingly sought after, and lower quality schools will lag behind. This happens in almost every city in Indonesia. In this globalization era, quality schools that provide more religious content are the first choice for parents in various cities. Religious education is the main capital to ward off negative influences in the era of globalization.

2. Implementation of education in schools cannot be separated from values, norms of behavior, beliefs, and culture. Especially schools run by Islamic foundations.

3. So far many people have the perception that school achievement is seen from the dimensions that can be measured and measured, especially the acquisition of computer-based national exam scores and the physical condition of the school. There is another dimension, namely software, which includes: Values, beliefs, culture, and norms of behavior which are referred to as the human side of organization which has more influence on the performance of individuals and organizations so that they become superior.

4. School culture has a strong impact on performance. School culture is a more important factor in determining school success or failure. If the stakeholder's performance is caused by the creation of a school culture that is driven by Islamic teachings and values, then that will be a double value ie on the side of the school itself, it will have competitiveness and comparative advantage while maintaining religious values as the nation's cultural roots, and on the other hand, the value of the principal includes teachers, and other education personnel as well as parents and students themselves. That means that they have practiced Divine values, 
ubudiyah, and muamalah, to get a lot of merits and have an effect on their lives later (Muhaimin,2006).

The method of habituation that is often called conditioning is an attempt to shape certain behaviors by practicing them repeatedly. According to Gagne, this method is called the direct method because this method is used intentionally and directly to change behavior. Learning conditioning methods are classified in the behaviorism approach and are a continuation of the learning connectionism theory. The principle of learning is that learning is the result of the relationship between stimulus and response. In connectionism learning theory or stimulus-response theory, it is explained that learning is a modification of the behavior of an organism/individual as a result of maturity and experience. Maturity and experience are the results of an ongoing training or habituation process (Munif, 2016).

Practically this method recommends that the learning process provides opportunities for students to practice directly (direct experience) or use substitute/indirect experience (representative experience). Students are given hands-on experience by getting them used to behave and behaving with values that apply in school and society. The practice of reading the Qur'an directly, shaking hands with the teacher, performing prayer in the congregation is an example of providing a direct experience.

In this habituation process, the learning process occurs because someone who is conditioned to get used to doing certain behaviors means he is trying to adjust to those behaviors. This is in line with Skinner's view that learning is a process of adaptation or a process of progressively adjusting behavior.

\section{DISCUSSION}

The development of religious culture in schools must have a solid foundation both in religion and in a normative constitution. So that all educational institutions together have a goal to develop a religious culture in their community. Therefore, good design and strategy are needed to develop religious culture while still paying attention and considering multicultural education.

The religious atmosphere in the school environment in various forms is very important for the process of instilling religious values in students. The process of instilling the value of Islamic religion in students in schools will become more intensive with the atmosphere of Islamic school life, both visible in activities, attitudes, and behavior, habituation, appreciation, and deepening. Marimba argues that the goal of Islamic education is the formation of people with Muslim personalities (Marimba, 1989).

Especially in the era of the industrial revolution where technology and information are very easily accessible, inculcation of religious values in schools plays an important role. Culture of mutual love, respect for others, and being moderate in religion must continue to be developed in the school environment.

School culture is all psychological practices of students both social, emotional, and intellectual that is absorbed by them while in the school environment. Psychological responses of students to daily life such as the way teachers and other school staff behave, the application of school policies, conditions and school services, the arrangement of beauty, cleanliness, and comfort of the school environment that can shape the school culture. All of that will affect the psychology of the school community including students which in turn will form patterns of values, attitudes, habits, and behavior (Muhaimin, 2006).

Implementation of the development of religious culture in schools will not run well if without the support and commitment of various parties, including the government, principals, Islamic religious education teachers, general subjects teachers, school staff, school committees, student support, institutions, and mass religious organizations and broad community participation. If all of these elements can jointly support and be involved in the implementation of religious cultural practices in schools, the goal of national education which is oriented towards the formation of people who are devoted to God will be realized and successful (Su'dadah,2014).

As a systematic effort to implement Islamic religious-cultural practices in schools it is necessary to be equipped with supporting facilities for the implementation of Islamic religious-cultural practices in schools including prayer rooms or mosques, supporting facilities for worship (such as ablution places, bathrooms, sarongs, pulpits), tools religious teaching aids, adequate libraries, halls or meeting rooms, classrooms as comfortable and adequate learning places, Islamic art equipment and equipment, multimedia rooms, computer laboratories, internet, and Islamic education laboratories.

\section{CONCLUSION}

Operationally religiosity is defined as the practice of life-based on the teachings of his religion, the response, or the form of treatment of the religion that is believed and adhered to and made as a way of life in life. Religiosity in its form can be judged by how a person's attitude in carrying out the commands of his religion and away from the 
prohibition of his religion. With this interpretation, religiosity can be understood as one's potential that makes it able to present the face of religion with the appearance of a humanist religious person.

In the era of the industrial revolution 4.0 as it is today, religiosity which should be the appearance of every educated human being after they attend Islamic education and teaching seems to fail. So that the inability of the practice of religious education in fostering an attitude of religiosity will be able to encourage the growth of negative human traits in wider social relations, such as violent behavior or other brutal actions. The failure of Islamic religious education in growing religiosity, it is suspected that the practice of Islamic education learning in schools is held to be of poor quality.

The learning developed so far has always placed the teacher as the center of learning so that the learning target is the provision of knowledge (transfer of knowledge), with the delivery of learning more of a normative text. Islamic religious education materials still occur many repetitions with previous levels and Islamic religious education materials are studied independently and are free from other fields of study. The learning methodology is delivered by some teachers in a static-indoctrination-doctrinal manner with a main cognitive focus that is busy teaching religious knowledge and regulations. The current pattern of religious education is still concerned with letters rather than the spirit, prioritizing literal interpretation over love. So that the learning of religiosity or religious diversity that should have been formed through religious education is ignored or failed to be realized.

This reality gives a signal that the implementation of Islamic religious education in schools faces several pressing problems to be solved so that the main mission to be carried out by Islamic religious education can achieve the target. The idea offered is to construct religiosity learning by taking into account the very dominant elements, including :

The formulation of the phasing or classification of achievement of learning objectives which are commonly called taxonomies must be formulated concretely, not only remain rooted in the Qur'an and Sunnah but also to realize the present life figure that can show direction, provide motivation and be a benchmark in evaluating activities.

The learning material is designed to achieve educational goals, based on revelation and which further provides practical solutions to the problems of the people. The offer that can be used as a basis is the scientific cum doctrinaire model with the essence of coherence techniques in the openness of practical appearance. This model is rooted in and originates in the Qur'an and Sunnah, but at the same time responds to an empirical display. Potential that will grow more leads to the emergence of religiosity behavior.
Religious learning must be relatively adaptive to the development and reality of the community by freeing itself from the dictates of history, reading and understanding the holy verses and the causes of their descent, and bringing out their ethical meaning.

Religious learning needs to be synchronized, collaborated, and interacted with non-religious education, making it easier for students to practice religion in their daily lives. This is operationalized more technically by way of every hour of religious education activities enriching general education programs, while every hour of general education activities will strengthen religious education programs.

\section{REFERENCES}

Al Qur'an danTerjemahannya, 2002. Departemen Agama Republik Indonesia.

Al Ghazi, Abu Qasim, 2005. Fathul Qarib Mujib, Beirut : Dar Ibn El Hazm

Awani, Agus, 2013. FORUM TARBIYAH Vol. 11, No. 1, Juni 2013 hal 83.

Darajat, Zakiah 1999. Perkembangan Psikologi Islam dan Pendidikan Islam di Indonesia. Jakarta : Penerbit Logos Wacana IImu, 1999

Ezmir, Data Analysis: Qualitative Research Methodology, Jakarta: Rajawali Press, 2012.

Fitriani, Annisa. Peran Religiusitas Dalam Meningkatkan Psycological Well Being. AlAdYaN/Vol.XI, No.1/Januari-Juni/2016.

Glock, C. Y., \& Stark, R. (1965). Religion and society in tension.San Francisco: Rand McNally

Henning, K. (2013). Recommendations for implementing the strategic initiative INDUSTRIE 4.0

Jalaluddin, H. (2008). Psikologi Agama, Memahami Perilaku Kegamaan Dengan Mengaplikasikan Prinsip-Prinsip Psikologi. Rajagrafindo Persada. Jakarta..

Kagermann, H., Luke, W.D., \& Wahlster, W. (2011). Industrie 4.0: Mit dem Internet der Dinge auf dem Weg zur 4. industriellen Revolution. http://www.vdinachrichten.com/TechnikGesellschaft/Industrie-40-Mit-Internet-DingeWeg-4-industriellen-Revolution, Accessed June 17, 2017.

Kagermann, H., Luke, W.D., \& Wahlster, W. (2013). Final report: Recommendations for implementing the strategic initiative INDUSTRIE 4.0. Industrie 4.0 Working Group. 
Marimba, Ahmad D, 1986. Introduction to the Philosophy of Islamic Education, Bandung, PT Al-Maarif.

Muhaimin. 2006. New nuances of Islamic Education: Unravel the tangled threads of the world of education, Jakarta: PT. Raja Grafindo Persada.

Munif, Muhammad, 2016. Pengembangan Pendidikan Agama Islam Sebagai Budaya Sekolah, Pedagogik; Jurnal Pendidikan, Vol. 3, No. 2 Januari-Juni 2016

Prasetyo, Hoedi, dan Wahyudi Sutopo, 2018.Industri 4.0: Telaah Klasifikasi Aspek
Dan Arah Perkembangan Riset, J@ti Undip: Jurnal Teknik Industri, Vol. 13, No. 1, Januari 2018 hal 18.

Su'dadah, 2014. Kedudukan dan Tujuan Pendidikan Agama Islam di Sekolah. Jurnal Kependidikan, Vol. II No. 2 November 2014

Suprayitno, Adi. Wahid Wahyudi, 2020. Pendidikan Karakter di era milenial. Yogyakarta: Deepublish Publisher.

Spinks, G. S. (1963). Psychology and religion: An introduction to contemporary views

\section{Copyright holder :}

Ahmad Rifa'I, Dewi Fatmawati (2020)

First publication right :

Journal of Social Science

This article is licensed under:

(c) (D) (?) 